\title{
Revisiting WebQuests to Develop Intercultural Communication Competence
}

\author{
Esther Stockwell \\ Hosei University, Japan
}

\begin{abstract}
The aim of this study was to investigate whether WebQuest activities could help students to understand various cultural contexts, with the goal of eventually improving their intercultural competence. The current study took place in in a private university in Japan, and utilized in-class WebQuest activities to promote students' participation in group and class discussions for critical reflection and self-assessment. Regarding education for intercultural competence, it focused on improving students' critical reflections and ability to self-assess their cultural standpoints through group and class discussion based on the WebQuest activities. The study used quantitative data collection methods along with analyses of students' reflections in their written and oral performances. The quantitative data were collected through pre- and post-surveys and an adapted version of the GENE (Generalized Ethnocentrism) scale questionnaires and the Intercultural Communication Competence scale questionnaires. This study demonstrated that the WebQuest tasks and the discussions helped to deepen knowledge of cultural-general and cultural-specific concepts. In addition, through group and class discussion, students helped each other not only to understand the content of the course but also to practice empathy in special situations in other cultures as explaining and sharing their understanding.
\end{abstract}

\section{Introduction}

Over the past several years, the majority of universities in Japan have aimed to bring up their students to have an ability to communicate with people from different countries effectively and be able to contribute to international society. To achieve this goal, most universities heavily focus on foreign language education, especially English language education [28]. It has recently extended to the development of various content classes conducted in English. However, while English language education in Japan requires a cultural component [15], this is rarely sufficient [28], even though it is well known that a lack of cultural awareness can hinder communication between people from different countries, even if they have sufficient language ability [32].

Teaching culture has proven to be a difficult undertaking in many respects. This problem is hardly new, and the problems of defining what culture is and how to teach it have been of concern to researchers for decades. Neuliep suggests that reducing ethnocentrism (i.e., the view of the relative superiority of one's own culture) can contribute to reducing psychological barriers that might impede uncertainty during initial intercultural interactions. While some degree of ethnocentrism is not necessarily a problem, in that it can serve to facilitate a sense of identity or community [23], if this becomes excessive, then it can result in formation of negative images of other cultures. Obviously ethnocentrism is just one aspect of intercultural competence, and being aware of one's own biases and stereotypes, as well as developing an openness towards other cultures, and an ability to interpret different practices, beliefs, discourses and values [5]. The complexities of culture are evident from this brief discussion, but how to teach learners to become interculturally competent is an area that is attracting attention

Barrett et al. [5] suggest that intercultural competence may be develped through both formal, informal and non-formal contexts, but the latter two contexts require the learner to be placed within the context, and is expected to take place over an extended period of time. Formal learning contexts requires the inclusion of planned components within the curriculum that lead directly to raising awareness of one's own culture and of other cultures, and should allow for comparison, experience, comparison, analysis, reflection and action. It is this last point which is of particular relevance to the current study, in that it includes engagement with others in intercultural discussion as a means of consolidating knowledge and ideas from other stages. Unlike many multicultural countries where there is cultural diversity in the classroom, Japan's comparably homogeneous 
cultural environment limits the opportunities students have to share their knowledge and experiences about other cultures in class, therefore alternative means are required to allow learners to have access to information and resources pertaining to other cultures.

The adoption of technology in learning about culture has prompted a movement away from approaches where learners are largely simply told about the target culture by the teacher. Learners can develop cultural awareness through accessing authentic online resources and/or active participation in construction of understanding of the target culture while reflecting on their own culture [33]. The following section provides an overview of how technology has been adopted in the development of intercultural competence.

\section{Technology and developing intercultural competence}

Using technology as a means of acquiring cultural knowledge is no longer particularly new, although this is typically limited to a particular culture rather than to leading learners to become interculturally competent in the broader sense. Technologies have made it possible to create environments for people to communicate with people from diverse cultures with relative ease. There is a good deal of research which shows that computer-mediated communication (CMC) and telecollaborative projects provide environments for students to communicate with people from diverse cultures and help students to develop intercultural competence [21], [16], [17] and [18] Examples of blogging, podcasting, email exchanges, and chat rooms used for cultural exchanges have appeared in the literature, and have shown to be motivating for the participants [8], [17] It has also been suggested that adopting technology to learn about cultures can help learners to reflect on both their own culture and the target culture, contributing to making them more interculturally competent [4], [11], as well as facilitating development from ethnocentrism to ethnorelativism [16], [21] point out that there is still a lack of research in technology-oriented intercultural learning environments, with a need for more empirical studies that evaluate different approaches to developing intercultural competence are needed, as well as pedagogies that balance cognitive, affective, and behavioural perspectives.

Simply being exposed to another culture does not guarantee that it will be adequately acquired, and nor is it expected to lead to immmediate development of intercultural competence.
Acquiring a culture is unlikely to be a spontaneous process, and indeed, many recent studies have revealed that merely communicating with people from different cultural backgrounds does not automatically lead to intercultural learning [25] [19]. While CMC makes it easier to bring people of differnt cultures together, the results of such studies suggest that a more explicit element of teaching or training is needed for cognitive or intercultural competence development.

As Müller-Hartmann [21] indicates, learners' critical reflection and self-assessment through intercultural discussion are key elements in intercultural learning. It is very important for learners to be aware of their present cognitive state regarding other cultures, such as their degree of ethnocentrism, racism, prejudices, and so on. If learners have stereotypical images about the target culture and interact with people from that culture, it is possible that their stereotyped image about the target culture will be confirmed rather than relieved [25], [6]. Therefore, it is important that learners have an opportunity to identify their current cognitive stage including stereotypical or biased images, or prejudices towards the target culture and whether or not they have a strong sense of ethnocentrism. Self-assessment of their present cultural cognitive state is one of the main ways to reduce negative results after learners interact with people from different cultures.

These reflections and self- limitations are not carried out instinctively. Learners need general cultural education, ongoing training or guidance to help them to think about their own culture and other cultures before, during and after interactions with people from different cultures. Intercultural researchers have suggested that learners must first be aware of their own culture, and also be exposed to general cultural education [22]. Once learners are aware of their culture and they know how to talk about their culture, they are better prepared to understand and discuss the values, expectations and traditions of others from an objective viewpoint based on general cultural knowledge [22]. In addition, intercultural competence is culture-general. That is, there are core competencies that individuals can develop that are not specific to any culture. Learners will also have their own hypotheses about cultural differences between own culture and others based on culturegeneral frameworks. After interacting with another culture, they should have the chance to test and refine their hypotheses about culture [31]. An opportunity to think about their own culture and other cultures before, during and after interactions with people from different cultures will give the learners chances to test and refine their hypotheses 
about other cultures from a relatively objective standpoint.

As described above, given the homogenous nature of many educational institutions in Japan, providing means of accessing authentic resources pertaining to culture is an essential part of successful development of intercultural competence. In the current study, in order to promote students' active participation in learning culture and to help students' understanding and reflection on various cultural contexts - including their own - this study explores web-based tasks using WebQuests and their impact on developing learners' intercultural understanding. WebQuests allow students to actively use various authentic resources that have been selected to meet their linguistic and cognitive needs to complete a task. That is, through WebQuests, instructors can select information considering their students' cognitive capacities and linguistic abilities. Through this guided learning environment on the Web by teachers, it is possible to reduce the risk of students losing the point of the task, and subsequently their motivation caused by the task being beyond their cognitive and linguistic abilities. There have been numerous studies which investigate the effects of WebQuests on enhancing students' motivation and engagement in class, and these have suggested a positive correlation [1]. The aim of this study is to determine whether WebQuest activities can help students enrolled in an intercultural communication class to understand various cultural contexts and improve their intercultural competence. The WebQuest activities were particularly used in class to promote students' participation in group and class discussions for critical reflection and self-assessment.

Regarding education for intercultural competence, based on various definitions and models of intercultural competence by many researchers, the most frequently described dimensions relating to developing intercultural competence include knowledge, attitude, skills and behaviours. For example, Wiseman [34] describes intercultural competence as the knowledge, motivation and skills to interact effectively and appropriately with members of different cultures. Kim [10] defines three dimensions specifically related to the concept of intercultural competence: 1. the cognitive dimension (individuals' interpretive structures assigning meaning to verbal and nonverbal messages), 2 . the affective dimension (individuals' motivations and attitude involved with willingness to accommodate different cultures), and 3 . the operational or behavioral dimension (individuals' flexibility and resourcefulness in carrying out the cognitive and affective dimension). In addition, Chen and Starosta [7] constructed an intercultural competence model that includes three perspectives that reflect the above approaches: intercultural awareness (cognitive), intercultural sensitivity (affective), and intercultural adroitness (behavioral). Therefore, in this study, for students to improve intercultural competence, these three perspectives; cognitive, affective and behavioral will be considered.

\section{Purpose of the Study}

This study is a follow-up of a pilot study by Stockwell [33]. The pilot study showed that WebQuest activities facilitated a general reduction in students' ethnocentricity and suggested that students had acquired a deeper understanding of both their own culture and other cultures through WebQuest activities. In addition, it demonstrated that WebQuests contributed to achieving the main objective of studying intercultural communication, namely, positively changing learners' perceptions and attitudes about their culture and other cultures. However, this earlier study looked at average trends and did not show individual changes in students' individual intercultural competence level and ethnocentrism levels. Therefore, this study has been conducted as a follow up to compensate for the limitations that were found through the pilot study. Firstly, with regards to measuring students' ethnocentrism, the pilot study did not allow correlation of individual results of the pre-test with post-test scores using the Generalized Ethnocentrism (GENE) scale questionnaire, but rather simply looked at mean pre- and post-test scores. Therefore, the purpose of this study is to examine changes in each students' individual scores on the GENE scale, and to add further quantitative data through the Intercultural Communication Competence Scale. The study also explores whether using the WebQuest tasks as class activities and carrying out group discussion in class are more effective than the out-of-class activities and online forums used in the pilot study. Regarding education for intercultural competence, the present study focuses on improving students' critical reflections and self-assessment ability through group and class discussion with the WebQuest activities.

\section{Method}

This study was carried out in a communication studies course entitled, "Glocal (Global and local) Communication" at Hosei University, in Tokyo, Japan during 2016. The course is an elective 
undergraduate communication studies course. The aims of the course are to enable students to be aware of and respect cultural diversity through exploring various cultural contexts and intercultural communication theories. There were 45 students from $1^{\text {st }}$ to $3^{\text {rd }}$ year enrolled in the course, and although it was not a foreign language course, the classes were conducted in English. The students generally were of an intermediate level of English, and important concepts of the lessons were presented and explained in both Japanese and English with visual materials, including photos, diagrams, video and so forth. The study involved concurrent collection of survey data and analyses of logs of learners' reflections through interactions in class and in a post-treatment essay. The quantitative data were collected through a pre-test and a post-test during the course.

\section{Data Collection}

All of the students who were enrolled in the course completed the Generalized Ethnocentrism (GENE) scale questionnaire to measure their ethnocentrism and the Intercultural Communication Competence Scale to measure their intercultural communication competence. They completed the same questionnaires on the first day and the last day of classes during the course. The one questionnaire was adapted from the GENE scale by Neuliep and McCroskey (1997). The GENE scale is composed of 22 items, 11 worded positively and 11 worded negatively, and is designed to reflect a conceptualization of ethnocentrism that can be experienced by anyone, regardless of their culture. The questionnaire is in the form of five-point Likert scales with scores on the GENE scale ranging from 15 to 75 , with higher scores representing higher levels of ethnocentrism (i.e., respondents are more likely to believe that their own culture is better). The reason for measuring the change in the degree of ethnocentrism is that ethnocentrism is an important dysfunctional variable to foster intercultural competence. Ethnocentrism refers to the idea that one's own culture is the center of everything and all other cultures scaled and rated with reference to it, and also one's cultural orientation acts as a filter for processing incoming and outgoing verbal and non-verbal messages. Ethnocentrism clouds our perception of others. That is, people tend to judge others and their communication, based on the standards set by their own culture. From a communication perspective, the disposition toward ethnocentrism might well be the characteristic that most directly relates to intercultural communication competence [29] Therefore, through measuring the degree of students' ethnocentrism, it is possible to understand their degree of openness and flexibility in attitudes toward other cultures.

The second questionnaire was adapted from the Intercultural Communication Competence Scale by Arasaratnam [2]. Arasaratnam and Doerfel [3] discovered that those who were identified as competent intercultural communicators possessed five qualities in common; empathy, intercultural experience/training, approach tendencies, a global attitude and listening skills. The global attitude especially describes individuals who are open to others, better at communication, show interest in differences and are aware of them. Based on these five characteristics, the Intercultural Communication Competence Scale was designed to measure one's intercultural communication competence. It was selected for the current study as it is suitable for measuring the change in the degree of students' intercultural competence for students in the course based on cognitive, affective and behavioral intercultural competence perspectives. The questionnaire is comprised of 15 five-point Likert scale questions, with scores ranging from 15 to 75 . Higher scores (above 55) indicate more intercultural communication competence and lower scores (below 35) indicate less intercultural communication competence.

\section{Course Design}

To improve students intercultural communication competence (ICC), the course was designed with four elements: (1) lectures about fundamental concepts about culture, (2) completion of WebQuests tasks, (3) group and class discussion, and (4) writing an essay. These are explained in more detail forthwith.

Lectures: Based on previous studies about developing ICC, it is important for students to have motivation to adopt other cultures. This motivation is related to having an open and receptive mind as well as a reduced degree of ethnocentrism. For this, teaching some basic but essential issues about culture is very important. Before students explore their own and other cultures, the lectures focused on fundamental concepts such as: culture is not innate but learned, how our culture influences our perceptions, behavior, language, habits, daily lives, various cultural patterns in the world, Hofstead's five characteristics of cultures, Hall's theory of high and low-context of culture, the $\mathrm{M}$ and P-time of cultures, and deceptive factors in intercultural communication such as stereotyping, racism, 
ethnocentrism and so on. These concepts (culturegeneral) are helpful for students to explore their culture and other cultures from a third person's position with open-mind. After studying culturegeneral, students learned culture-specific knowledge about their own culture and cultures from other countries.

2. WebQuest activities: There were two main purposes of using WebQuest activities. Firstly, the WebQuest was used to give students opportunity for reflection and self-assessment of intercultural discussion about ethnocentrism, racism, and prejudices. It made learners realize their present cognitive and emotional motivation to cope with encountering culturally unfamiliar settings. Below are some examples of topics for the WebQuest tasks:

(a) Please watch the video showing that American children have prejudice towards other races on the class web page. (b) Then find information for the following question using resources through the WebQuest. (c) Discuss the following questions in your group:

3. Why do little children think this way?

4. What would you do if you were their parents?

5. Have you seen any kind of discrimination, such as gender, race, education, or age in Japan?

6 . What do we need to do to reduce prejudice in our multicultural society?

The second purpose of doing the WebQuest activities was to make students actively be aware of their own culture and other cultures through finding some of the roots or backgrounds of the images and behavior of their own culture and other cultures. In completing the WebQuest tasks, students needed to find out general images and fixed images of Japan(ese) and America(ns) from their communication styles, business activities, school or daily lives, and so on. After identifying these images, they needed to find out and explain the historical background of how these images came into being, the social organizational structure, religions, language, and the diverse cultural patterns such as may be defined through Hofstead's five characteristics of cultures, Hall's theory of high and low-context of culture, the M and P-time of cultures, and so on. Lastly, they needed to identify the unique cultural patterns for Japan(ese) and America(ns).

Topics for the WebQuest tasks were:

1. Find out general images and fixed images of Japan(ese) and America(ns).

2. Find out how these images came into being. You can explain these images through the historical background, the social organizational structure, religions, language, and the diverse cultural patterns and so on.

3. Identify Japanese cultural patterns and American cultural patterns based on the results of what you find.

All of the resources needed for the tasks were selected online by the instructor, taking into consideration students' cognitive capacities and linguistic abilities. The various resources were selected to maintain students' motivation to find out the necessary information, and thus included a balance of both heavy and light contented materials such as academic sources, news reports, personal blogs, and video materials written in either Japanese or English. These activities were carried out in class over a seven-week period combining both individual work and group work (consisting of around four students).

Group and class discussion: After finishing the WebQuest tasks, students shared their experiences, and discussed their perceptions and understanding about the WebQuest tasks in group and class. Group discussion before class discussion was deemed as important for the Japanese students because it allows them to support and confirm their views with each other. Through doing this, it is much easier for students to voice their opinions confidently in front of other people in class discussion.

Essay writing: Students were required to submit a reflective essay based on the lectures and WebQuests by the final day of the course. Students were asked to organize their knowledge from the lectures and the WebQuests for the semester. The final essay dealt with:

What is "internationalization" and "being a globalised person"

What does "Every individual is a product of their culture" mean?

\section{Results and Discussion}

The main purpose of this study was a follow-up of a pilot study by Stockwell [33], compensating for the limitations that were found through the pilot study. The findings and discussion are focused on two issues. Firstly, with regard to examining whether the WebQuests were effective in reducing students' ethnocentrism, correlation of individual results of the pre-test with post-test of the GENE (Generalized Ethnocentrism) scale questionnaires and the ICC (Intercultural Communication Competence) Scale were conducted. Secondly, the findings were based on determining whether or not using the WebQuest tasks as class activities and carrying out group discussion in class are effective for increasing student's intercultural awareness 
and sensitivity.

\section{Change in the degree of ethnocentrism and ICC}

Firstly, in order to measure changes in the level of ethnocentrism and Intercultural Communication Competence, Table 1 summarized the means and standard deviations of the results of the pre-test and post-test the GENE scores and ICC scores for students. Higher mean scores indicate higher ethnocentrism and more intercultural communication competence. Scores above 55 on the GENE scale are considered as high ethnocentrism, whereas higher scores (above 55) on the ICC indicate more intercultural communication competence

Table 1. Means and Standard Deviations of GENE Scale Scores and ICC Scale Scores

\begin{tabular}{|l|c|c|c|}
\hline & $\mathrm{N}$ & $\mathrm{M}$ & $\mathrm{SD}$ \\
\hline $\begin{array}{l}\text { Pre-test } \\
\text { GENE }\end{array}$ & 45 & 32.93 & 7.11 \\
\hline $\begin{array}{l}\text { Post-test } \\
\text { GENE }\end{array}$ & 45 & 25.93 & 6.32 \\
\hline Pre-test ICC & 45 & 44.62 & 5.98 \\
\hline $\begin{array}{l}\text { Post-test } \\
\text { ICC }\end{array}$ & 45 & 47.64 & 5.02 \\
\hline
\end{tabular}

Overall, students' ethnocentrism mean score reduced from 32.93 before the WebQuest class activities to 25.93 after the course. In addition, students' ICC mean scores increased from 44.62 before the WebQuest class activities to 47.64 after the course.

In order to determine whether adopting WebQuest activities with discussion are effective in reducing individual student's GENE scores, a paired t-test analysis was adopted. The paired t-test calculates the difference within each before-andafter pair of measurements, determines the mean of these changes, and reports whether this mean of the differences is statistically significant. Table 2 presents GENE scale results of paired-sample $t$ tests and showed declines in the ethnocentrism scales and which were statistically significant $(p$ $=.001)$ and positively correlated $(p<.001, r=.50)$.

Table 2. Means and Standard Deviations of GENE Scale Scores Paired Samples Test

\begin{tabular}{|c|c|c|c|c|c|c|c|}
\hline \multicolumn{4}{|c|}{ Paired Differences } & \multirow{7}{*}{$r$} & \multirow{7}{*}{$\mathrm{t}$} & \multirow[b]{2}{*}{$\mathrm{d}$} & \multirow[b]{2}{*}{$\mathrm{Si}$} \\
\hline $\mathrm{M}$ & Std. & St & $95 \%$ & & & & \\
\hline ea & Dev & d. & Confide & & & $\mathrm{f}$ & g. \\
\hline $\mathrm{n}$ & iatio & Er & & & & & $(2$ \\
\hline & $\mathrm{n}$ & ro & Interval & & & & - \\
\hline & & $\mathrm{r}$ & of the & & & & tai \\
\hline & & $\begin{array}{l}\text { M } \\
\text { ea }\end{array}$ & $\begin{array}{l}\text { Differen } \\
\text { ce }\end{array}$ & & & & $\begin{array}{l}\text { le } \\
\text { d) }\end{array}$ \\
\hline & & $\mathrm{n}$ & \begin{tabular}{l|l} 
Lo & U \\
\end{tabular} & & & & \\
\hline
\end{tabular}

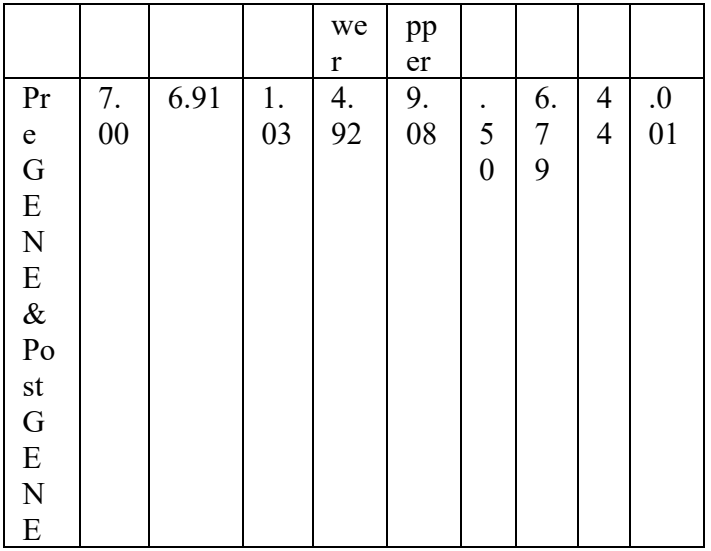

This figured showed larger drops in each students' ethnocentrism scale scores than the results in the pilot study. Comparing between the pilot study and this study, the main difference was assigning significantly more time for students' reflection about their and others culture through group and class discussion with WebQuests activities in class than in the pilot study. Other aspects, such as the class content and the results for pre-test of GENE scale did not exhibit much difference between the pilot study and this study. This results showed that reflection through group and class discussion on both one's own culture and the target culture did not only increase intercultural understanding but, to a certain extent, also resulted in an attitude change or a development of a positive attitude toward other cultures. In addition, each student shifted in the positive direction of greater ICC scale (see Table 3). These shifts were statistically significant and highly positive correlated $(p<.001, r=.60)$.

Table 3. Means and Standard Deviations of ICC Scale Scores Paired Samples Test

\begin{tabular}{|c|c|c|c|c|c|c|c|c|c|}
\hline & \multirow{7}{*}{\begin{tabular}{|l|}
$\mathrm{Pai}$ \\
$\mathrm{M}$ \\
$\mathrm{ea}$ \\
$\mathrm{n}$
\end{tabular}} & ed Dif & renc & $S$ & & & & & \\
\hline & & \multirow{6}{*}{$\begin{array}{l}\text { Std. } \\
\text { Dev } \\
\text { iatio } \\
n\end{array}$} & \multirow{6}{*}{\begin{tabular}{|l}
$\mathrm{St}$ \\
$\mathrm{d}$. \\
$\mathrm{Er}$ \\
$\mathrm{ro}$ \\
$\mathrm{r}$ \\
$\mathrm{M}$ \\
$\mathrm{ea}$ \\
$\mathrm{n}$
\end{tabular}} & \multirow{5}{*}{\multicolumn{2}{|c|}{$\begin{array}{l}95 \% \\
\text { Confide } \\
\text { nce } \\
\text { Interval } \\
\text { of the } \\
\text { Differen } \\
\text { ce }\end{array}$}} & \multirow[t]{5}{*}{$r$} & \multirow[t]{5}{*}{$\mathrm{t}$} & \multirow{5}{*}{$\begin{array}{l}\mathrm{d} \\
\mathrm{f}\end{array}$} & \multirow{5}{*}{$\begin{array}{l}\mathrm{Si} \\
\text { g. } \\
\text { (2- } \\
\text { tai } \\
\text { le } \\
\text { d) }\end{array}$} \\
\hline & & & & & & & & & \\
\hline & & & & & & & & & \\
\hline & & & & & & & & & \\
\hline & & & & & & & & & \\
\hline & & & & $\begin{array}{l}\text { Lo } \\
\text { we } \\
\text { r }\end{array}$ & $\begin{array}{l}\mathrm{U} \\
\mathrm{pp} \\
\mathrm{er}\end{array}$ & & & & \\
\hline $\mathrm{P}$ & - & 4.97 & .7 & - & - & . & 4. & 4 & .0 \\
\hline re & 3. & & 4 & 4. & 1. & 6 & 0 & 4 & 00 \\
\hline I & 02 & & & 51 & 53 & 0 & 8 & & \\
\hline $\mathrm{C}$ & & & & & & & & & \\
\hline $\mathrm{C}$ & & & & & & & & & \\
\hline$\&$ & & & & & & & & & \\
\hline $\mathrm{P}$ & & & & & & & & & \\
\hline $\begin{array}{l}\mathrm{o} \\
\text { st }\end{array}$ & & & & & & & & & \\
\hline
\end{tabular}




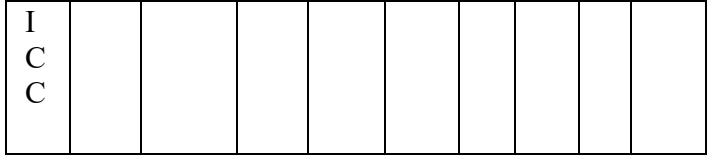

Intercultural communication competence encompasses both cognitive and affective domains [13]. The cognitive aspect of intercultural understanding comprises knowledge about one's own as well as other cultures. While knowledge is an important component, it is not enough for intercultural communication competence. Positive attitudes towards other cultures are also necessary, such as flexibility, open-mindedness and respect [9]. Therefore, the results showed that in order to build up students' intercultural competence, focusing on both cognitive and affective domains is important.

\section{The use of WebQuests in class}

In the pilot study the use of WebQuest tasks was examined as an out-of-class activity to assist students to prepare for their written assignment. In this study, the WebQuest tasks were used as class activities in the lectures and for carrying out group discussion in class. It was found that using WebQuests as class activities with lectures were more effective than the only out-of-class activities and online forums used in the pilot study in terms of the GENE scales and ICC scores. Firstly, it helped students to understand the content of lectures even some more abstract concepts such as cultural patterns and models or theories of intercultural communication through various examples in the WebQuest resources. Secondly, face-to-face discussion allowed students to share their experiences and learning more actively and provided them with a greater chance to share their ideas and think about them more deeply and widely. Face-to-face discussion in group and class motivated students to give their own opinion and discuss issues because they could have instant responses without limitations of space and time unlike the online forums. In addition, the teacher could have some idea about finding and using the WebQuest resources depending on the class contents because the teacher could see how students used the WebQuest resources in class. The teacher could provide assistance about using the WebQuest resources to students immediately if required. Most of all, students actively participated in the lectures and discussions as a result of doing the WebQuest tasks in class rather than doing the WebQuest tasks as out-of-class activities. This motivation and active participation of students is thought to link to the result of reducing the degree of ethnocentrism and improving students' intercultural communication competence scale.

One clear observation was that students tried to link cultural general information (including the fundamental cultural concepts) and theories covered in the lecture to the WebQuest resources. In the beginning of the study, many students described about other cultures as comparing differences and commenting on similarities with their cultural view. However, they began to analyze and understand other cultures linked to their historical, geographical, political, and religious aspects. In addition, there were several comments about cultural general information such as "Culture is not innate, but learned," "Culture has a great impact on people's thoughts, attitudes, behaviors," "There is no good culture or bad culture, instead there are only familiar cultures and unfamiliar cultures" and so on. In fact, in the same course in previous years when WebQuests were not used, there were many comments from students regarding simple comparisons between Japanese culture and other cultures, but most of these comparisons were based on a Japanese cultural perspective. Students in this study showed a more open mind to looking at other cultures, as may be illustrated with the following example: "When I looked at American people who come to Japan, they look very rude and noisy. They talk with each other loudly in public places. However, I found out that they have learnt to say their opinion clearly since they were young, and it is very important to communicate in their multicultural society. I realized that different society systems can shape people's communication styles." Moreover, students reflected on their culture from the perspective of others, for example "I thought smiling is a universal non-verbal code, however, I was surprised that the timing of when to smile is different depending on culture. Japanese people often smile when they make small mistakes, which is quite different from American culture. Therefore, we should be careful with smiling because even smiling can cause misunderstanding." The fact that students mentioned and understood these concepts provides some evidence that they understand the fundamental concept of culture with an open and flexible mind. It also indicates that they developed their cognitive and affective skills in intercultural competence.

\section{Conclusion}

This study revealed the critical role of WebQuests as a potential tool in the development of students' intercultural competence. The course 
was designed based on the idea of cognitive, affective and behavioural dimensions encompassing intercultural communication competence, as established through past research. In order to maximize the effects of the course, this study adopted WebQuest tasks as class activities coupled with group and full-class discussion during class.

This study demonstrated that the WebQuest tasks and the discussions helped to deepen knowledge of cultural-general and culturalspecific concepts. In addition, through group and class discussion, students helped each other not only to understand the content of the course but also to practice empathy toward special situations in other cultures as a means of explaining and sharing their understanding. This process appeared to be helpful to lead students to develop affective dimensions in intercultural communication competence, such as having an open and flexible mind and practicing empathy. These positive results are linked to the results of the GENE and ICC scale. Regarding the ICC scale, students' ICC level improved when comparing scores from before and after the course. Students in the course using WebQuest tasks and in-class group and class discussion showed larger changes positively about students' ethnocentrism than were indicated in the results from Stockwell's earlier study using WebQuest tasks out of class [33].

The study was not, however, without limitations. In this paper, students' reflections in their written and oral performances was analyzed to show their improvement of cultural understanding and their attitude changes about different cultures in a positive way. However, it needs more systematical qualitative data collection and analysis methods to measure students' reflections in their written and oral performances. This would provide more effective and solid results regarding improvement of intercultural competence.

It is important that learners have an opportunity to see their current cognitive stage including stereotypical or biased images, or prejudices towards the target culture and whether or not they have a strong sense of ethnocentrism. Selfassessment of intercultural discussion regarding their present cultural cognitive state is one way to reduce potential negative results that may arise when learners interact with people from different cultures. In addition, using WebQuest activities in conjunction with in-class group and class discussion provides a forum for these reflections and self-assessments allowing students to be exposed to different cultural issues from various perspectives. The results of the study question the premise that simple exposure to other cultures is sufficient to result in deepening learners' views towards their own and other cultures, and rather, that positively promoting discussion of cultural issues can lead learners to hold a more balanced view, which is likely to lead to greater cultural understanding.

\section{References}

[1] Altstaedter, L., \& Jones, B. (2009). Motivating students' foreign language and culture acquisition through web-based inquiry. Foreign Language Annals, 42 (4), 640-657.

[2] Arasaratnam, L. A. (2009). The development of a new instrument of intercultural communication competence. Journal of Intercultural Communication, 20. Retreived from http://www.immi.se/intercultural/nr20/arasaratna m.pdf. (Access Date: 15 June 2013)

[3] Arasaratnam, L. A., \& Doerfel, M. L. (2005). Intercultural communication competence: Identifying key components from multicultural perspectives. International Journal of Intercultural Relations, 29 (2), 137-63.

[4] Angelova, M., \& Zhao, Y. (2014). Using an online collaborative project between American and Chinese students to develop ESL teaching skills, cross-cultural awareness and language skills. Computer Assisted Language Learning, 29(1), 167-185.

[5] Barrett, M., Byram, M., Lázár, I., MompointGaillard, P., \& Philippou, S. (2013). Developing intercultural communication through education. Strasbourg: Council of Europe. Retrieved from http://www.academia.edu/3150166/Developing_I ntercultural_Competence_through_Education.

(Access Date: 15 June 2013)

[6] Belz, J. A. (2003). Linguistic perspectives on the development of intercultural competence in telecollaboration. Language Learning \& Technology, 7(2), 68-117.

[7] Chen, G. M., \& Starosta, W. J. (1996). Intercultural communication competence: A synthesis. In R. B. Brant (Ed.). Communication Yearbook 19. Thousand Oaks: Sage Publications.

[8] Chun, D. M. (2011). Developing intercultural communicative competence through online exchanges. CALICO Journal, 28 (2) 1-28. 
[9] Deardorff, D. K. (2006). Identification and assessment of intercultural Competence as a student Outcome of Internationalization. Journal of Studies in Intercultural Education, 10, 241-266.

[10] Kim, Y. Y. (1991). Intercultural communication competence: A systems-theoretic view. In S. Ting-Toomey \& F. Korzenny (Eds), Cross-cultural interpersonal communication (pp. 259-275). Newbury Park: Sage.

[11] Keranen, N., \& Bayyurt, Y. (2006). Intercultural telecollaboration: In-service EFL teachers in Mexico and pre-service EFL teachers in Turkey. TESL-EJ, 10(3), 1-50.

[12] Kitade, K. (2012). An exchange structure analysis of the development of online intercultural activity, Computer Assisted Language Learning, 25(1), 65-86.

[13] Hill, I. 2006. Student types, school types and their combined influence on the development of intercultural understanding. Journal of Research in International Education 5 (1). 5-33.

[14] Hirasawa, Y. (2009). Multicultural education in Japan. In J. A. Banks (Ed.), The Routledge international companion to multicultural education (pp. 159-169). New York: Routledge.

[15] Hosoki, Y. (2011). English language education in Japan: Transitions and challenges. Kyushu International University Studies in International Relations, 6(1-2), 199-215.

[16] Lee, L. (2011). Blogging: Promoting learner autonomy and intercultural competence through study Language Learning \& Technology, 15(3), 87-109.

[17] Lee, L. (2012). Engaging study abroad students in intercultural learning through blogging and ethnographic interviews. Foreign Language Annals, 45(1), 7-21.

[18] Lee, L., \& Markey, A. (2014). A study of learners' perceptions of online intercultural exchange through web 2.0 technologies. $\operatorname{ReCALL}$, 26(3), 281-297.

[19] Liaw, M. L., \& Bunn-Le Master, S. (2010). Understanding telecollaboration through an analysis of intercultural discourse. Computer Assisted Language Learning, 23(1), 21-40.
[20] Moore, Z. T. (2006). Technology and teaching culture: What Spanish teachers do. Foreign Language Annals, 39 (4), 579-594.

[21] Müller-Hartmann, A. (2007). Teacher role in telecollaboration: Setting up and managing exchanges. In R. O'Dowd (Ed.), Online intercultural exchange: An introduction for foreign language teachers (pp. 264-268). Clevedon, UK: Multilingual Matters.

[22] Neuliep, J. W. (2012). The relationship among intercultural communication apprehension, ethnocentrism, uncertainty reduction, and communication satisfaction during initial intercultural interaction: An extension of Anxiety and Uncertainty Management (AUM) theory. Journal of Intercultural Communication Research, 41 (1), 1-16.

[23] Neuliep, J. W. (2015). Intercultural communication: A contextual approach $\left(6^{\text {th }} \mathrm{Ed}\right)$. London: SAGE.

[24] Neuliep, J. W., \& McCroskey, J. C. (1997). The development of intercultural and interethnic communication apprehension scales. Communication Research Reports, 14, 385-398.

[25] O'Dowd, R. (2003). Understanding the "other side": Intercultural learning in a Spanish-English e-mail exchange. Language Learning \& Technology, 7(2), 118-144.

[26] O'Dowd, R. (2007). Evaluating the outcomes of online intercultural exchange. ELT Journal, 61(2), 144-152.

[27] Perry, L. B., \& Southwell, L. (2011). Developing intercultural understanding and skills: Models and approaches. Intercultural Education, 22(6), 453-466.

[28] Rivers, D. J. (2010). Ideologies of internationalization and the treatment of diversity within Japanese higher education. Journal of Higher Education Policy and Management, 32 (5), 441-454.

[29] Samovar, L., Porter, R., McDaniel, E., \& Roy, C. 2014. Understanding intercultural communication: A Reader. (14 ${ }^{\text {th }}$ ed.). Belmont, CA: Wadsworth.

[30] Schenker, T. (2012). Intercultural competence and cultural learning through telecollaboration. CALICO Journal, 29(3), 449-470. 
[31] Seelye, H. N. (1993). Teaching culture: Strategies for intercultural communication. Lincolnwood, IL: National Textbook Company.

[32] Sherry, M., Thomas, P., \& Chui, W. H. (2010). International students: a vulnerable student population.

Higher Education, 60(1), 33-46.

[33] Stockwell, E. (2016). Using web-based exploratory tasks to develop intercultural competence in a homogeneous cultural environment. Journal Innovations in Education and Teaching International 53(6), 649-659.

[34] Wiseman, R. L. (2002). Intercultural communication competence. In W. B. Gudykunst, \& B. Moody (Eds.), Handbook of international and intercultural communication ( $2^{\text {nd }}$ ed.) (pp. 207-224). Thousand Oaks, CA: SAGE. 